\title{
The contributions of Nan Goldin's photographic work with the formation of a plural humanism
}

Aportes de la obra fotográfica de Nan Goldin a la formación de un humanismo plural

Iván Darío Moreno Acero

Universidad de la Sabana, Colombia

ivandario1983@hotmail.com

Nelson Hernando Puentes Rodriguez

Universidad Santo Tomas, Colombia

dcultu@mail.ustabuca.edu.com

\begin{abstract}
Faulkner wrote about a small community and wrote around 25 great novels and several short stories. They were always located in a place he loved, with an invented name, but it was a real place. Everything was based on what he knew. I've always thought I have the right to photograph only my own tribe or people when I travel, whose I approached and give them something

Nan Goldin (2003)
\end{abstract}

We are all dominated by a stagnant conception of what is important and irrelevant, we keep looking in anguish at what is important, while the irrelevant, covertly and behind us, extends its guerrillas, that ultimately without us realising change the world, and we are caught unaware.

Milan Kundela (1999, p. 282)

\begin{abstract}
In the last two centuries the photography in its function to retain the immediately brief and momentary present, has been a central narrator of the human history, not only as a passive narrator of events, but also as an active one, to say it as a tenacious sensitizer of the situation that the human being and its society has lived. The photographic work of Nan Goldin in the investigation group "Ehics, pedagogy and literature" has been assumed as a narrative that thinks about human condition throughout history, as well as a vehicle that goes beyond established limits. In general, we propose that photography is a central element in the humanist formation because it makes the individual thinks about himself in a new way.
\end{abstract}

Key words: humanist photography, Walter Benjamin, Nan Goldin, education, humanist formation. 


\section{Resumen}

En los dos últimos siglos, la fotografía, en su ejercicio de retener la inmediatez del breve y pasajero presente, ha sido un narrador central en la historia humana, pero no solo como un informador pasivo de los eventos, sino también como uno activo, es decir, como un sensibilizador tenaz de la situación que la sociedad ha vivido. La obra fotográfica de Nan Goldin, dentro del grupo de investigación "Ética, pedagogía y literatura”, se ha asumido como una narrativa que permite reflexionar ampliamente en la condición humana a lo largo de la historia y, a la vez, como un vehículo que permite ampliar sus horizontes establecidos. En general se propone que la fotografía sea un elemento central en la formación humanista, ya que desde ahí el sujeto se puede concebir de una manera distinta.

Palabras clave: fotografía humanista, Walter Benjamin, Nan Goldin, educación, formación humanista.

Fecha Recepción: Agosto 2014 Fecha Aceptación: Febrero 2015

\section{Introduction}

Within the investigation group "Ehics, pedagogy and literatura", there have been some discussions about the relationship between ethic and literature. One of the objectives of this group is to understand the contributions of some literary and artistic narrations toward the extension of the ethic capacity, thus the criteria used by subjects to act and justify their ethic actions everyday. This investigation that is been taking place since January 2013 and will be finished by December 2014, has a qualitative character and it is methodologically grounded in the "theoretical sampling", this will allow us to track the information extensively, to codify the emergent categories, and finally to formulate a hypothesis to explain the main problems that have been recognised in this investigation. As one of the results of this project and the constant discussions that have taken place, in order to have the dimension of the contribution of the art toward the ethics, we propose in this article in which the photography in general is analysed -following Walter Benjamin's proposal- and the documental humanist photography by Nan Goldin -in particular-, as a narration that taken to the educative domain allows us to make a wide reflection about the need to think the human from other horizons, a reflection 
that affects the way in which the educators look at the other as heterogeneous beings, who have our owns rights and as a result the same recognition as worthy social subjects.

Think about photography as a didactic strategy that broaden our capacity to act ethically, it is what is raised here, as the opportunity to develop a human and plural perspective that tends to eliminate the speeches and social practices in which the horror is privileged, to be specific, the everyday practices which segregate and attack other subjects, either because of their social condition or their sexual identity.

In the first part of this text, the photography is approached as an artistic activity that catches the aura in a significative event, at the same time as an artistic expression that has the possibility to narrate and approach to an understanding of the humankind; the starting point to analize is Walter Benjamin literary work. In the second chapter, Nan Golding work is studied according to its humanistic potential as his work is read as a narrative from which is posible to rethink the human, granting new sense categories and taking as significative the ways in which its characters are constituted according to their life orientation. In the last part we explore the contribution of the photography to the formation of an ethic criterion to judge and act more humanly. In general, the conclusion is that it is not posible to get rid of the photography as an element to form an ethic criterion of the learners, since this artistic expression has the strenght to generate a higher discussion about the importance to highlight in other contexts and situations, the human that there is and could be in us. This encourage to reduce the possibilities to install a totalitarianism and the horror as a permanent scene in our society.

\section{First part: The photography allows the narration and definition of the human: an appreciation based on Walter Benjamin's work}

Since the beginning, the photography has been shown as an instrument that allows the human being to represent the decisive instants of everyday, as well as, to figure out and perpetuate the elusive beauty, that for a moment and from certain angle, it can capture in nature, it could be from an object, a society or a subject. The photography has particular elements that are behond the classic problem of imitation, open a panorama of discussion unfinished and fathomless for the philosophy and specially for the humanism, since its primitive apparition with Joseph Nicephore Niepce, or with its first positive meddling in the French society by Louis Daguerre, has raised the challenge into philosophy to think about the instrument, the 
technique, the art and the implications of the new perspective that the photography brought, some social implications, other ethics, educative and others that throughout the time have been read, some implications of humanistic character, that have made us to rethink us, while we develop a critic conscientious less opportunistic or tending to the whitening reiterative that Jean Baudrilard on its test "La gran colada" critic in an inclement way.

This is an awareness that broaden our moral sensibility and the capacity to reflect ethically, thanks to those images that have allow us to think about the scope of horror in the concentration camps, either right or left, or the consequences of the wrathful progress as a product of a type of economy and the social order, it has been generated educative works against some types of violence; such us photographic work that shows the violence of gender, or the case that will be analysed in this text, the everyday of the excluded and out casted subjects in United States.

The photography is an art: and the arts, Herbert Read said (1965),

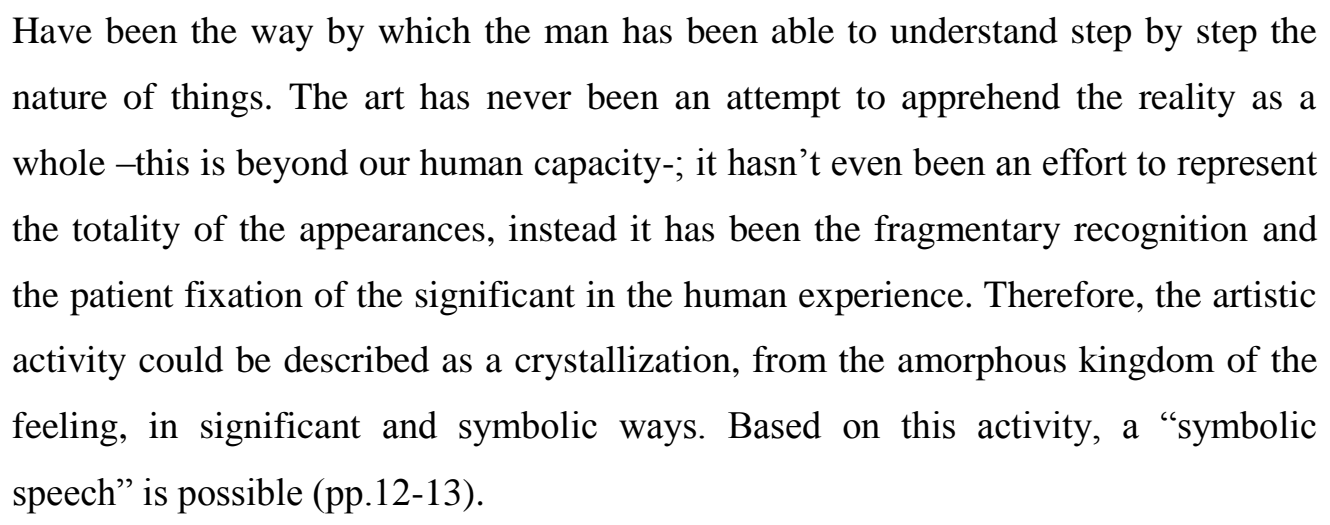

The art of the photography builds a narration about what is happening in the everyday, makes the reader closer to a diminutive situation in which he/she can see if it is interesting and stop for some seconds to catch the message, some symbols that to recreate a minimun aspect of the situation raises the photographied object; a situation that to be significant triggers an amotion that being rationalized allows to create, for itself or for other, a reasoned judgement or perspective about the cathegories that are there. The photography allows the comprenhention of our pass for this world as species, through what results to be significant and has the virtued to say something about how we have constituted historically, even though, this is not an ideal process, neat, without perfidy and always progressive. This type of 
art shows with its own technique, - which is to captures and gives aura to a moment that was significant for the photographic artist-, that "unsuspected treasure of analogies and shapes (the plants for the Walter Benjamin case or that of a person who is ecstasy of barbiturates in Nan Goldin's case) feat that only the photography can pursue. Then it is necessary a vigorous extension so its forms can despoil the veil that our laziness has put over them" (Benjamin, 2008, p. 12).

The photographer stole an scene from a certain time and space that won't be repeated, but right now is numb, available for a spectator attentive, able to see the implicit and immediate message and at the same time give it a subjective sense, personal, whereby this fragment serves to create a goal-history, an underlying story that brings an image of a new implication that can go from the political to the cultural, from the ideological to the most shameless erotic reviews.

Understanding this as a dialectic relationship between the image and the observer, between the capacity to express that posses the photography and the capacity and the willingness of who see it, to see in it something clear, but also to give it a new sense and a new meaning, to reiterate it according to its multipurpose needs. In this case, the photography has a sense for itself, that is given and emerged in function of the artist, on the other hand, it has a social sense, as it is attributed a reclaim effect throughout which a fault is compensated or a virtuous quality is exalted in an object or in a scene in which the main figure is the subject and what it is expressing, likewise a personal, private attribute could be attributed that leads to pleasure, to the imaginary fulfilment and doesn't belong to its dream: or that leads to see it to deny and reject a repulsive act, to tell us that is should never has happened, it will never be repeated.

On 4th February 1930 Walter Benjamin, in one of his usual cultural articles that he published by order; on his own desire of write and comumnicate a picture of the world and for the pleasure of posterity, highlighted, from a simple conversation held with the librarian Adrienne Monnier, a contribution that she gave him and which is neccesary towards it perception related to photography and generally for a wide component of his estetic theory,

\footnotetext{
"The big creations" says cannot be considered the work of an only individual. They are collective settings, they are so powerful that can only be enjoyed by reducing their size. Deeply, the mechanic reproduction methods are a reductive technique.
} 
They help the man to reach that level of domain over the work, without it they could not been enjoyed". That way I changed a vierge sage photo in Strasbourg, one that we talk about at the beginning of our meeting, for a reproduction theory, that perhaps could resul more valuable (2008, p.18).

It was a valuable input, as this ordinary conversation to some scrupulous people and insignificant to those who engage philosophical exegesis, made possible that in the first draft in 1935 or in its fourth version in 1939 of its writing " The artwork on its technical reproducibility period", Benjamin exalts the importance of the art of the photography and how aberrant and confusing was the discussion about the artistic value of its products, as in both cases exist and prevail the cultural value (2008, p. 107). Hence our "German Philosopher ", - referring to the title that was denied in live and that on its grave shines ironically, as George Steiner said (2003) on its essay "Talk about Walter Benjamin" -, present a lecture about photography, in which highlights and describe its aura and the potential that has this form of art. The photography is to Benjamin a vital space of the subjects, as the expression of the human face, the Schelling one or the one of a mysterious confectioner, or an empty road in a French commune that confers "an incomparable melancholic beauty" (2008, p. 107), it is an strange emotion that shake us, and wake us up in an irrational way, towards an image that evokes something which is familiar but that cannot be recognise or grab easily, but it offers the certainty that there exists something beautiful, something beautiful associated to the darkness of the image, with the glance of the character, as Benjamin stands out with the costume wrinkles; it is an estrangement disturbing but beautiful, - this results undeniable if we address our look to the desolate road in Paris or in Man Ray photographs, Stone,Germaine Krull or Elí Lotar, artists-photographers that the "German philosopher" knew properly:

On photography (Benjamin narrates following the text "Little history of photography" published in serials in 1931) .... Something new and special comes to our way: in that fisher from New Haven who is looking at the floor with such a modest indolence, so seductive, remains something that doesn't exhaust the testimony of art from the photographer Hill, something that resists to be silenced and claims without indulgence the name of who lived here and is still here, without wanted to ever get into "art" altogether (Benjamin, 2008, p. 24). 
The photography is magic (Benjamin, 208, p. 26), as it evoques suggestively something new and durable, it doesn't exhaust that reborn, any time that image that impacted us cross our daily activities. There is no difference between the technique and the magic (2008, p. 26), both things are misterious and lead the subject to approach the nature of the human being in a vital way, without abstruse interferences, as we see there in each miniscule aspect something that tell us about what we are; a being that does not resist a unique answer, as we are not in function of a category that defines arbitrary our condition or life, and what we are weaves in an infinite number of physiognomic features, expressions and attitudes, within other things it can catch the photographer and it is useful to think us as other unfolded. The technique and the magic of photography shown the aura,

The images revealed against the exotic resonance, splendorous and romantic of the city names, absorb the aura of the reality like the water in a ship when it is sinking. But, what properly is the aura? A very special length of space and time: the unrepeatable apparition of the remoteness, even if it is close. In midday during the summer, follow calmly the profile of a mountain chain in the horizon or a branch that projects it shadow over who contemplate it, up until that moment or hour became part of its appearance, this means to breath the aura of those mountains, the branch (Benjamin, 2008, pp. 41-42).

From the author's perspective, the photography allow us to get close to a world in which we can "breath the aura" of the object protographied. An aura that cautivate and is unconfortable, this give us the opportunity to ask some questions related to the esthetic, politic, social or ethic. The photography is a vehicle that no only bring us closer to a situation, to a fragment of the history, but it leads us to a type of specific problema, with it we generate a monologue that locate us in a place of that problem, a simple image transport us to a moment, it also has the ability to put us in front of what to see. For example, we can see in Dorothea Lange's work in which the rural lifestyle of the American's workers is explored, simple people who live their lives in poverty, who live in misery conditions, one that can be perspired and we fell it in each photography that shows the features that have produced the fight for survival, strong features acompanied by miserable contexts that tell us something about life in 1935, but that allowed us in 2013 to think about the conditions of the people who live from working in the countryside. Benjamin said that it was possible to do a comparative study about photography, then let's do it, based on Lange we can cross his work with Ituano Rimaldas Viksraitis work, 
we should listen sincerily to what both of these artistic samples have to tell us about rural life: at a point it can be found that the laborer's life is cruel; it is found in another point; the capacity to love and to show its sensuality is unheard, but at this point there is a separation, a split occurs; Lange's characters love each other discreetly, always silent, on the contrary Rimaldas's characters uninhibitedly get undressed, they enjoy nude, the simplicity of their lifes and the fury of their desire. The photography is a narrative that with its own language describes the world, but it doesn't use a close narrative, it is open to conclusions, to give a twist to its plot, but without giving a definite conclusion.

\section{Second Part: The humanist photography by Nan Goldin allows to rethink the human}

"Deep inside the photography is subversive, but not when it frightens, upsets and stigmatizes but when it is thoughtful" (Barthes, 1989, p. 73). Subversive when it gives us something to think at the very instant when it reaches us. The photography raises the reflection, transfors the image that it holds about reality, as it has been said, shocked, namely subverts the order of what is given, of what is considered univocal and of one facet; in each scene, it teaches us that the world and the ways to live on it are countless. The photography as love, even if it is only one, has diverse ways to express oneself, to give in each context and in function of the artist's needs or the lover. One of these expressions of the photographic art is the humanist. Our lives and perhaps other's peoples lives are documented with the humanist photography, another who seems familiar narrates it changes and conditions, narrate just as in a custom or autobiographical soup opera, the experiences and situations that a human group experiment on its pass for the world. This narration of the every day life of a person or social group is never neutral because it is built with the aim to enunciate something in particular, either the genesis of a pain or existence.

The humanist photography has a main concern: the human being. It is a concern that leads to build a poetic body, of everyday life, its needs, fears, hopes, the dedicated figth for happiness; it is a decadent poetry and exhuberant beauty that is not pleased with faking the reality by showing unreal situations; but neither polirizing it speech, babbling that everything is wrong and therefore there is not salvation from the horror in which have sank the humans being. The photography, as it reivindicate the values given to life, thus it confers a message of hope, in which it urgues to love live in any way it is lived, despite of the non-acceptance of homoerotic scenes or that offend an emasculating and segregating moral. I has an ambiguous 
technique, it is reminiscent and prospective; it is evocative as based on past images, it relates how the existence was and how it happened and why there, in that place and moment, was dignify, here there is a work model that educate and sensitizes our capacity to ethically judge.

In foresight, considering what has been seen, and starting from the permanent effect of his message, the spectator is prepared to think and work towards and adequate future to reach its highest fulfilment, according to its identity, gender, political views or sexual preferences. The image gives the possibility to believe in different future, tailored to the needs of the new identities that are forming.

Throughout her work, Nan Goldin is positioned in our society as a humanist: someone who thinks about the human being, its condition and foremost the ways in which it is constituted or it is subjective in front of a closed totality, that overwhelms, marginalized or deny the possibility to opently express whatever he or she is. The work of this artist is in first person, from oneself who deconstructs reality, its immediate context or that communal life that has resulted fundamental to understand epistemologically the construction of knowledge or the processes to constitute the identity. Nan Goldin displays a critic view about its everyday life that allows her to enunciate a speech about the most beautiful people that she has seen on her life and for her they became her world (Goldin, 1993). The technique that she uses is simple, plays with the light, and confers to the photographied faces and situations the most explicit message; that human life is display in unexpectedly beautiful shapes, so what we see through her lens is the 70s and 90s reality, which is denied and is hidden to the point to be considered illegal. She registered the life of some human beings that have been marginalized for their wishes to make latent their heartfelt opinion of life, their identity and their insubordinate eroticism. It is a technique that shows the toughness to document life, to count the transformation that occurs in the human being on their attempt to be coherent; to live being faithful to their variable nature -if we want dynamic-, to the desire that overwhelms their bodies to love restriction of gender or social conditions, and to the pleasures that brings the unusual intake of heroin and cocaine.

Initiated in Boston, the big Goldin "visual diary" found its shape, registries and material in New York at the beginning of the eighties, a city where bohemian art and the sexual live were changing to a very fast rhythm like the rules of the art market. While she earned a living working in bars, Goldin set up her camera and 
flash quickly with the polymorphs signs of an historic after hours luck, in which the old categories that until them had defined the identity and the experience (art/life, masculine/feminine, public/ private, personal/politic) seems to crumble and madden, intoxicated in a plural modernity, impure, blatantly anti-dogmatic. After a stop in the world of the drug Queens... Goldin start working in the disturbing personal narrative with which still today, after thirty years, we identify her. She photographed her friends, roommates, lovers and travel companions. The photography applying makeup in the bathroom before going to a party; crying, talking, making love or sleeping in solitary beds after parties. Immediate, quick, non-intrusive, Goldin's photos document so much that often they represent a memory or juridical evidence. For instance, they remind of what the alcohol and the drugs deleted from her mind or help her to settle friendly controversy showing how things really happened. Sometimes, these are all at once: portrait, document, proof, monument, diagnostic, desperate cry for love, cry for help (Pauls, 2012, p. $1)$.

If in this moment we ask ourselves, what is valuable about Nan Goldin work for the contemporary philosophy and toward the humanistic education, we can find, without effort that on it the worries about the identity crises (Jimmy Taboo), the crossing and the reformulation of genres (Misty and Jimmy Paulette in taxi), the sexual violence (Self portrait), the social exclusion (Drag queens), the constant transformation of the being (Kim Harlow), the body and the sexuality (Bobby masturbating), a personal moral that guides the behavior of a subgroup of society and the value to manifest, justifying their tastes and pleasures (Ectopic pregnancy scar), they appear to be relevant ideas, structured ideas that orientate her work. The proof can be found in "The Ballad of Sexual Dependency", in "The other place" or in "Ballad from morgue" in which explicit - founding epistemologically- the perspective of its work and the importance that it poses to broaden the human frontiers: a humanism open to understand and dialogue with a type of human condition in which is important to value the meaning and sense that is given to some basic rituals in which the body is glorified, taking care of it aesthetically, allowing its full pleasure, so private or public, without fear of damaging or hurting it, infect it, as these are seen as ills from an external point of view, but from the point of view of the protagonists of the story, this was vital for their lives, then the pain, the HIV or the overdose were the result of possessing themselves without limits, in a disproportionate manner which at the same time was passionate. Goldin told in an interview made in 2003 in Warsaw that: 
The photography has saved my life. Any time that I am going through something that scares me or seems traumatic, I survive by doing photographies... My work is mainly about the memory. For me, it is very important to photograph the people who have been close to me in my life. People who have gone like Cookie, that was very important to me, however, still exists the series of images showing how complex she was. Since, these photographies are not statistic; they don't show people dying, instead about particular lives... (My work, could say Goldin is in the first place) about the politic of gender. Related to what is to be men or women, which are the roles of the gender... Especially, The Ballad of Sexual Dependency is especially about all the politics of gender, even before that the word existed, before it was taught in university. I didn't make the decision to do a work related to the politics of gender. I did that exposition about my life, about my past. Later on, I realised that it has a political connotation. It is structured in a way that it talks about diverse couples, happy couples... Treat about violence, about belonging to a set category of men or women, then children, the way they are raised, and those roles, and later men, so it shows too much violence, the violence that men play with (Goldin, 2003).

This is an intimate work that deals with the ways in which the members of a social group underground are constituted as subjects, throughtout antagonistic and marginal social practices; diverse. Each image of Goldin's work is an epitome, in which a discussion is opened, initially aesthetic, so she hits what she hates and is considered decant and therefore inhuman; HIV, homosexuality, sex dependency, drug addiction, the night and its travesty angels who dance and sing erotically, a renovated human sense, as for them their social practices are significant; it is from and according to them how they nominate and consider human beings; these are everyday actions through which they constitute as individual and give sense to their place in the world. On the other hand, her documental work open other discussions that are related with other facets of the human being: 1 - The public and private conduct of people who should live isolated because of their identity, 2- The importance of the sexuality and its rol in the development of life, and 3- The gender and its open transgression. These topics that Golden show us in relation to her "family" (Children 1976-1996), actually are fundamentals to the social sciences and honest education, as the topics are basics from which we think about human condition as something unfinished, in progress, that daily thanks to the particular social practices is broaden and enriched, despite the violence with 
which the existence of these emerging narratives are denied or the existence of other social groups, their rights and values, so human, political and social.

With the proposal of Benjamin about photography we learned that, art as such has the strenght to trigger thinking, to takes us further on that the formal speeches and open us to contexts, subjects, fenomenous, and undreamed practices, in general, the aura of a something, or a somebody of who we didn't have any knowledge; but now it has affected us. With Nan Goldin, the words of our "German philosopher" make sense. In every scene, undeniable arguments are found about the diversity with which life is given, about love, the pain, the tragedy, or the personal value given to the existance, about the uncertainty of the human dignity. In this work there is an aura, that make us rethink what is considered as human, while the morally unacceptable and aberrant, the unnatural or monstrous behavior, the sick and dirty, the decadent, or that which erodes and conducts to the end of the human, now it is a path that brings us to understand ourselves as different beings, heterogeneous, for whom being men or women is not important, as I can be both, love and want like both at the same time, without affecting me; today following Goldin and Queer's theory, I can be a female, tomorrow a male, the day after tomorrow a man, next week a woman, without implying that I stop being Benjamin, Goldin or Ivan. Generally, Golden's visual narrative is a work that drive us to think of other social and personal situations that as the religious believes, the marriage is the church marriage, the heterosexuality between other things constitute the human being, therefore it enable us to understand each other widely. However, there is an unrestrictive possibility of understanding the human through photography. It is mediate by an educative work, in which individuals are educated to open theirs perspective and to develop a sensitive and fraternal spirit, in Benjamin words (2008) it implies generating on the learner the capacity to extract an ethic knowledge, as "extract (from plants or we could also think to extract from the human being) all the sweetness of the chalice is still reserve to fraternal spirits, also giants; to solar eyes like those that Goethe and Herder had" (p. 14).

\section{Third part: Educate humanly and ethically throughout Nan Goldin's photography}

In a classic essay, writeen by Susan Sontag and called "In Plato's cave", it gives an horizon to look in order to understand the relationship between photography and education:

The humanity persists irredeemably in the platonic cave, still delighted for ancestral customs, with pure images of the truth. But, get educated by photography 
is not the same as get educated by more antiquated images, more crafted. Firstly, there are a lot more images in the surrounding that claim our attention. The stock taking started in 1839 , since then everything has been photographed, at least this is the way it seems to be. This same avidity of the photographic view changes the conditions of confinement in the cave and our world. By teaching us a new visual code, the photography alters and broadens our notions of what it worth it looking and about what we have the right to observe. They are grammar but overall an ethic of the vision. Finally, the most imposing result of the photographic determination is giving the impression that we can contain the whole world in the head, as an analogy of images (2006. p. 15).

However, what claims our attention is in the actuality and that help to develop a cautious educative action, thus, that responds efficiently to the needs to strengthen in the learners the capacity to critic, an ethic criteria, at the same time, a broaden sensibility towards cojuntural subjects in our local and global context. There is more than one answer to this question, on the contrary, it is infinit the number of themes that require our attention; moreover, that fundamental is that the photography is a crucial element to start a conversation and trigger within the students the aesthetic sensibility, raises the ethic criteria and the critical analysis, as well as the capacity to translate into other codes the everyday experiences; what happens in life. As it has been said, the photography is a didactic element that can be used to develop together with the students a human perspective, that allow us to comprehend and understand as dinamic beings, diverse, in development, that we build ourselves via everyday social practices, that being heterogenous seems to be very valuable as that heterogeneity breaks the essentialist understanding that the only thing that they do in to perjudice the individual, as these censured the particular ways in which are obtained.

The humanism is a horizon to educate, in which educative actions can be orientated to potentiate some social and ethic abilities that help the learners to understand that some aspects such as the sexual that differentiate us as individual are proper and valuable characteristics of the personality of each subject. Understand their differences, importance and their value, leads to consolidate open social matters and to accept the other radically, to respect, not only to tolerate but to include and recognize them as social subjects of laws. It has been said that the education is a social action with anthropologic character having as main function to perfect or develop to its highest the social abilities of the learners; however, 
the education above its instrumental function in which it reproduces codes condescendingly, behaviors, structures of power and control pre-established, has produced stillness in the social capacities, even though the political guidelines insist that the education is a sensitizing and transmitting action of human values and virtues, some perspectives are needed and benign to develop an open and fair society, that mutually accepts the differences, these are excluded from the classroom and the political guidelines in which the diversity is a subject that keeps on being avoided easily, which is not looked up in depth, and it is not required to be understood and dealt with by the teachers and teacher's directors and their students, as an example we can cited the modules to orientate the "Programs of sexual education in Colombia" or the " 6 th basic standard guide for teaching citizenship skills" in which a theme like respecting differences is treated with overwhelming shyness. Maybe, this lack of orientation and training in these types of theme could be one of the causes in the proliferation of homophobic situations in schools, colleges and universities in which 7 out of 10 students consider that the sexual diversity is associated to an illness, aberration or sin. In this regard, it is important to study the report of The National Pedagogic University and the Corporation to promote citizenship forward since 2007 under the leadership of Erik Cantor Jiménez, who analyses the exclusive and negative perspective held about homosexuals, lesbians, transgender or bisexuals and raises the discussion about the urge to work these themes and generate understanding about how important it is to act and coexist humanly in the 21th millennium (Cantor, 2008).

A humanitarian education should be plural, address the diversity and exalts the importance of differences, without taking away the value of human dignity or cancelling diversity, denying the plurality of shape that is held in each social context; the reason against the fulfilment of a humanitarian and plural education, could be according to a prominent text by Marguerite Yourcenar who called "A civilization of repressed compartments", the inability of human beings to imagine and simulate that nothing happens, that we are all equal in absolute mode, that we love, understand and make sense of everyday life in the same way.

Oscar Wilde (affirms Yourcenar) wrote somewhere that the worst crime is the lack of imagination: the human being does not feel compassion in relation to bad situations that they have not experienced directly, not even in relation to those situations to which they have not assisted. I often thought that the sealed wagons and the well-built walls in the concentration camps assured the spread and duration 
of crimes against humanity that could have finished before if those have been taken place in the open air and in the eyes of all. The customs in the public squares in the Middle age of the big century, without doubt that situation immunized some spectators; there was always someone who got emotional, even though did not protest loudly, the murmur was finally heard. The executers of today's high works take better precautions (1991, pp. 203-204).

Nan Golding work takes out of anonymity the life conditions of a specific social group, it evidences the particular ways in which they live and assumes the sexuality as a main feature of our personality, it talks about things that could be better to forget, so if we talk to youngsters about that, it could be possible for them to familiarized with the monster that torment us, and therefore they could start to act like them. Presenting a Goldin's photography as an artwork and as a current speech which sensibilisers on three different themes that her work proposed, but in front of our eyes there is something that we cannot hide any longer, something that reveals and demystified that human condition is unique, that our nature is univocal and as such make us think that we are mysterious beings that we are still comprehending dialogically. Closing to that permanent comprehension is a crime: like believing that the gitano's people, the Jewish, the Palestinian or indigenous are not human's towns but irrational animals, fill for not humans: a crime like believing that homosexuality "is an inclination objectively disorganized" (Ratzinger, 1986). Then, horror should be abolished, those practices held by our collective unconscious that make possible the spread of new control or extermination camps, where "different" people are confined, either as sick or subversive, sick people who should go to vacation camps to cure their problem, who should avoid going on the street transvestites so they don't infect the youngsters, so they have especial areas for that aim, tolerance areas where their behaviour can be accepted and could not cause any problem to spotless minds, fragile and malleable of boys, girls and youngsters, since in the future we want them to be good citizens and no "sick" people who go against the work of civilization.

Abolish the horror, as well as the reductionist views of what make us humans should be a task to deal with urgently in the principal education areas, otherwise, we will continue advancing towards the creation of sophisticated and innovative concentration camps; new Gulags where some attentive and humanitarian scientists provide to their "weird" patients daily dosage 75 milligrams of Ludiomil (antidepressant produced by Novartis) and 20 
milligrams of Dogmatil (antineurotic produced by Sanofi-Aventis S.A.) additionally, ten Lords's Prayer and ten Virgin Mary's Prayer, all these with the aim to find normality and come back to be a human (Inzunza, 2010). New Auschwitz where humans are split from no humans to avoid a catastrophic mix, also identify and recognize with symbols and nicknames to the others who are not like us. The photography helps to comprehend these themes, but also allows us to think about the scope of institutionalization of horror and will make possible, without the adventurous of the historic whitening that will help to forget the crimes against humanity, treat like common some themes that are vital to answer the elusive question, who are we?; the exercise is very simple and only has two steps: 1- reflect about your teacher ethos, 2- think that you teacher profession should not be dogmatic, therefore it should be a human exercise, 3- take into account that your teacher's labour should not be exclusive or contrary to strength the will and freedom of the students, 4- chose a subject that you consider vital to the integral development of the students, hence it would allow them to be more human, it will be less prone to get affected by other subjects, 5- substantiate your arguments theoretically, remember that this foundation should not have as main source the principal ideologists of the totalitarian extermination programs, persecution programs and control of the no humans (the sick), 6- Chose the adequate images to think and rethink the human, 7- frankly talk to your students and together recognize that the value of the human can also be found in conducts the previously were considered "objectively disorganized", incorrect politically or just immoral, 8- lastly, understand that study the behaviour of other subjects that decide to live subverting the genders, re-meaning through their sexuality their identity and living according to their own moral principles, it is ethic and leads to broaden the perspective of the human, and therefore to transform gradually the everyday dangerous practices that always hold the hope to configure a world for the selected, those who in this case did not dare to go against what was accepted and valued as good and moral, "the normal”.

\section{Conclusion}

Generally, the photography as an educative tool is lent as an instrument to humanize and desmantle the perspectives that don't know others facets of our human condition. On this aspect, the photography is a strong sensibilizer that opens other ways to be human and to be assumed as a social subject of rights in every context. However, this is a point of view that even though is desirable, depends on the teacher's work, his or her intentions to confront the students with real subjects, to show the diversity of shapes of being human, to make them 
more flexibles to the importance of this reciprocal comprehension and over the damaging effects that has the negation of the other, its persecution and social siege. The teachers are called to develop the human labour to untiringly look for highlighting the value of life, the freedom and the inalienable rights with which count human beings. The teachers are humanizing agents that have the task to form humanly and ethically their students, despite that other learning environments like the family, the social media, or the cultural mechanism trumpet that there are some humans, who are more human than others, and hence that some have the right to live and others not; to this teachers must insist and forge a criteria of thought and action open to mutually accept the differences, and to the continuous renewal of what is understood as a human. Here literature, music, painting or a photograph of Nan Goldin, which make a poetic of minimum components of life, can serve as an educator element that will lead to that desired prospective horizon.

\section{Bibliography}

Baudrilard, J. (2000). Full screen. Barcelona: Paidós.

Barthes, R. (1989). The lucid camera. Note on photography. Barcelona: Paidós.

Benjamin, W. (2008). On photography. Madrid: Pre-Texts.

Cantor, E. (2008). Homophobia and coexistence at school. Bogotá: Editorial Fund National Pedagogical University.

Goldin, N. (1993). The other side. New York: Scalo.

Goldin, N. (1994). A double life. New York: Scalo.

Goldin, N. (1980). The Ballad of Sexual Dependency. New York: Scalo.

Goldin, N. (2003). Interview by Adam Mazur and Paulina Skirgajllo-Krajewska. 13th February 2003, Warsow.

Inzunza, A. (2010, 20th June). Prayers to stop being gay. El País, p. 20. 
Kundera, M. (1990). The Book of Laughter and Forgetting. Bogotá: Seix Barral.

Nussbaum, M. (2006). The concealment of the human. Disgust, shame and law. Buenos Aires: Katz.

Pauls, A. (2012). Ballad of Sexual Dependency. Malpensante, 132(6).

Ratzinger, J. (1986). Letter to the Bishops of the Catholic Church about the care of homosexual people. Vatican City.

Read, H. (1965). Image and Idea. México: FCE.

Sontag, S. (2006). On Photography. México: Alfaguara.

Yourcenar, M. (1991). Time, the great sculptor. Buenos Aires: Alfaguara. 